\title{
Desain Livestock Carrier Rute Makassar - Jakarta Untuk Menyuplai Kebutuhan Sapi di Jakarta dan Sekitarnya
}

\author{
Muhammad Ulul Fikri, Hesty Anita Kurniawati \\ Jurusan Teknik Perkapalan, Fakultas Teknologi Kelautan, Institut Teknologi Sepuluh Nopember (ITS) \\ Jl. Arief Rahman Hakim, Surabaya 60111 Indonesia \\ e-mail: tita@na.its.ac.id
}

\begin{abstract}
Abstrak-Konsumsi daging sapi di DKI Jakarta yang meningkat menyebabkan kebutuhan akan sapi terus bertambah. Sulawesi Selatan merupakan salah satu daerah sentra peternakan sapi yang saat ini perkembangan peternakan sapinya mulai meningkat. Hal ini membuat Sulawesi Selatan dapat dijadikan daerah untuk memasok sapi untuk memenuhi kebutuhan daging sapi untuk daerah Jakarta dan Sekitarnya. Namun sarana transportasi laut untuk komoditas ternak sapi yang menghubungkan Sulawesi Selatan - DKI Jakarta masih kurang memadai. Livestock Carrier dapat sepenuhnya menggantikan kapal kargo dan kapal kayu kapasitas kecil untuk mengangkut kebutuhan sapi antar pulau karena kapal ini dapat mengangkut sapi dalam jumlah banyak. Selain itu Livestock Carrier dilengkapi sistem sanitasi yang baik untuk menjaga kebersihan dan kesehatan sapi selama proses pengangkutan. Pada Tugas Akhir ini didesain sebuah Livestock Carrier yang mengangkut ternak sapi. Kapasitas muatan kapal didapat dengan menggunakan data dari kebutuhan daging sapi di daerah Jakarta dan Sekitarnya, kemudian dicari deadweight dan ukuran utama dari kapal. Dengan ukuran utama yang didapat kemudian dilakukan analisis hidrostatik dan stabilitas, lalu dibuat desain sistem sanitasi, Rencana Garis dan Rencana Umum. Lalu didapatkan kapal dengan payload 1020 ekor ternak sapi dan dengan ukuran utama Lpp: 107,5 m; B: 18,0 m; H: 8,0 m; T: 4,2 m; dengan rute Pelabuhan Soekarno - Hatta di Makassar, Sulawesi Selatan, menuju Pelabuhan Tanjung Priok di Jakarta.
\end{abstract}

Kata kunci-Livestock Carrier, Makassar, sapi, Sulawesi Selatan.

\section{PENDAHULUAN}

$\mathrm{T}$ INGGINYA konsumsi daging sapi di DKI Jakarta mengakibatkan kebutuhan akan daging sapi itu sendiri meningkat secara drastis, peternakan sapi di DKI Jakarta yang jumlahnya tidak banyak belum bisa memenuhi permintaan daging sapi yang meningkat. Menurut Asnawi (2015) mengatakan bahwa untuk DKI Jakarta, dibutuhkan sekitar 700 ekor sapi impor perhari, sedangkan untuk sapi lokal sekitar 1400 ekor sapi per hari, ini disebabkan karena ukuran sapi lokal lebih kecil dari sapi impor dengan berat berkisar 250-300 kg untuk sapi lokal, dan $500 \mathrm{~kg}$ untuk sapi impor. Oleh karena itu satu - satunya cara yang dapat dilakukan adalah mendatangkan sapi dari daerah lain di DKI Jakarta. Salah satu daerah yang merupakan pemasok sapi DKI Jakarta adalah Provinsi Nusa Tenggara Timur. Sebanyak 353 ekor sapi dari NTT telah memasuki Jakarta sejak 11 Desember 2015, namun pasokan sapi yang datang hanya akan memenuhi $1 / 4$ hari kebutuhan daging sapi lokal untuk DKI Jakarta [1]. Untuk memenuhi kekurangan pasokan daging sapi maka pemerintah Provinsi DKI Jakarta bekerjasama dengan pemerintah Provinsi Sulawesi Selatan. Sulawesi Selatan merupakan daerah sentra peternakan dan pengembangbiakan sapi potong baik itu berupa badan usaha milik pemerintah dan swasta. Pengembangan peternakan sapi yang mulai tinggi di daerah Sulawesi Selatan membuat banyak investasi untuk peternakan sapi semakin tinggi. Hal ini juga membuat Sulawesi Selatan dapat dijadikan daerah untuk memasok sapi untuk memenuhi kebutuhan daging sapi untuk daerah Jakarta dan Sekitarnya. Proses pengangkutan (transportasi) sapi sering kali membutuhkan waktu yang lama sehingga sapi sering mengalami stres selama perjalanan. Namun selama ini alat transportasi yang digunakan sebagai sarana pengangkutan sapi tidak dirancang baik untuk mengangkut sapi. Penyediaan pakan dan minuman sepanjang perjalanan juga tidak memadai, peralatan bongkar muat dan penanganan sapi menggunakan moda transportasi tersebut jarang diperhatikan kelayakannya. Lamanya waktu transportasi dikarenakan lokasi antara daerah sentra konsumsi dengan daerah produksi berjarak relatif jauh. Dengan kondisi negara kepulauan, jarak yang relatif bejauhan tersebut selain harus ditempuh menggunakan transportasi darat, kegiatan distribusi sapi juga harus menggunakan transportasi laut. Kondisi demikian menyebabkan biaya transportasi yang relaif tinggi, berupa biaya transportasi langsung (biaya angkutan), biaya transportasi tidak langsung untuk tambahan tenaga kerja dan pakan sapi akibat jadwal angkutan yang tidak teratur, serta biaya penyusutan berat badan sapi akibat tidak memadainya perawatan dan sarana angkutan selama kegiatan pemuatan [2]. 


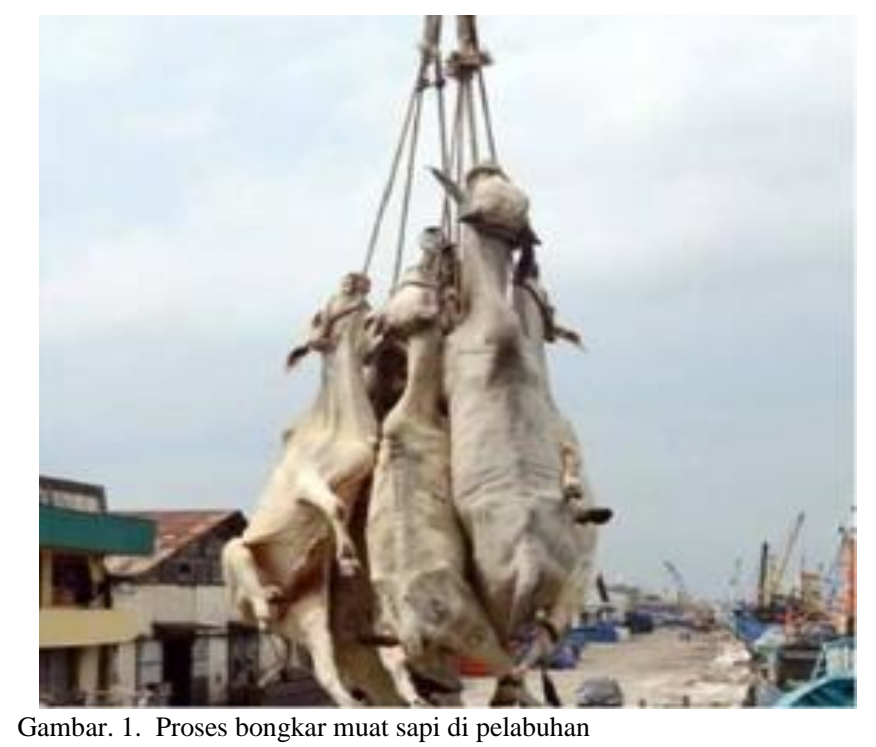

Dari gambar di atas diketahui bahwa untuk proses bongkar muat sapi secara tradisional sangat memprihatinkan, dimana sapi diangkat menggunakan crane untuk dipindahkan dari kapal ke pelabuhan maupun dari pelabuhan ke kapal. Oleh karena itu diperlukan suatu teknologi pengangkutan sapi yang ramah lingkungan dan bisa membantu memenuhi kebutuhan sapi sehingga dapat mengurangi resiko penurunan berat dan juga bisa mencegah kematian sapi pada saat pengangkutan. Salah satu inovasi yang dapat mengatasi masalah tersebut adalah dengan menciptakan Livestock Carrier. Livestock Carrier yang dimaksud disini adalah teknologi pengangkutan khusus sapi menggunakan moda transportasi laut yang memperhatikan kelayakan dan kenyamanan untuk sapi yang diangkut, baik saat proses bongkar muat maupun saat proses pengangkutan sapi. Kapal juga harus dilengkapi sistem sanitasi yang baik untuk menjaga kebersihan dan kesehatan sapi selama proses pengangkutan.

\section{TINJAUAN PUSTAKA}

\section{A. Livetock Carrier}

Livestock Carrier adalah kapal yang digunakan untuk mentransportasikan binatang ternak hidup seperti sapi, kambing, dan domba. Kapal ini pada umumnya dibuat secara khusus atau merupakan konversi dari kapal kontainer atau kargo. Jenis Open Livestock Carrier dipilih karena umumnya memiliki kandang yang dipasang di geladak terbuka, secara teori, hal ini menyediakan ventilasi yang natural secara berkelanjutan di area kandang dan dapat menghindari ketergantungan dari sistem ventilasi mekanik. Ventilasi adalah kunci utama dalam transportasi hewan yang masih hidup. Ketika kandang hewan memiliki ventilasi yang buruk, deplesi oksigen dan gas beracun yang dihasilkan akan berkembang dengan cepat [3].

\section{B. Sewage Treatment Plant}

Pembuangan sewage dari kapal yang sedang berlayar memiliki ketentuan khusus untuk menjaga kebersihan dan ekosistem yang ada di laut. Oleh karena itu pembuangan sewage dari kapal harus dilakukan perlakuan khusus sebelum akhirnya dibuang ke laut [4]. Sewage Treatment Plant dengan metode biologis dipilih karena menggunakan bakteri yang berfungsi sebagai pengurai unsur sewage sehingga bisa diterima untuk dibuuang di laut. Bakteri yang biasanya digunakan adalah bakteri oxygen loving, bakteri ini bekerja dengan mencerna sewage, membuat biaya operasionalnya relatif murah. Selain itu jenis ini mudah digunakan.

\section{METODOLOGI PENELITIAN}

Metodologi dalam pengerjaan penelitian ini digambar dalam diagram alir (flow chart) pengerjaan sebagai berikut:

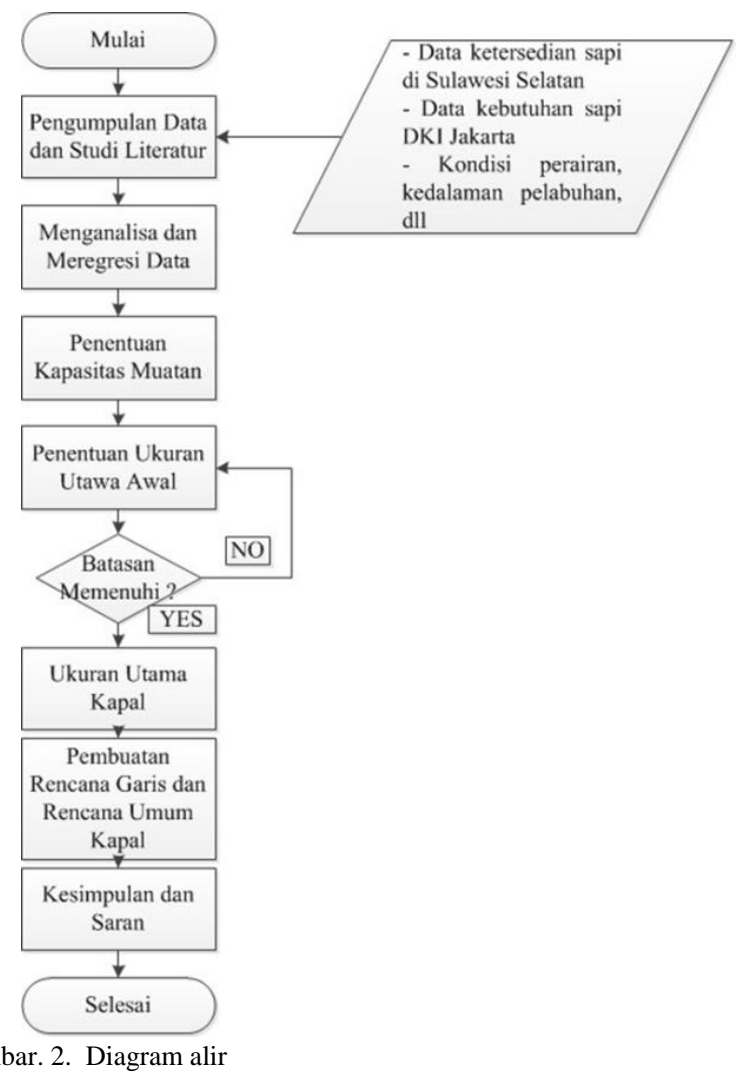

\section{ANALISIS TEKNIS}

\section{A. Perencanaan Muatan}

Sulawesi Selatan merupakan salah satu provinnsi dengan populasi sapi terbesar di Indonesia. Menurut data populasi sapi yang dikeluarkan oleh Badan Pusat Statistik tahun 2015 mengalami peningkatan tiap tahunnya. Pada grafik di bawah dapat dilihat jumlah populasi sapi Sulawesi Selatan tahun 2011-2015 [5]. 


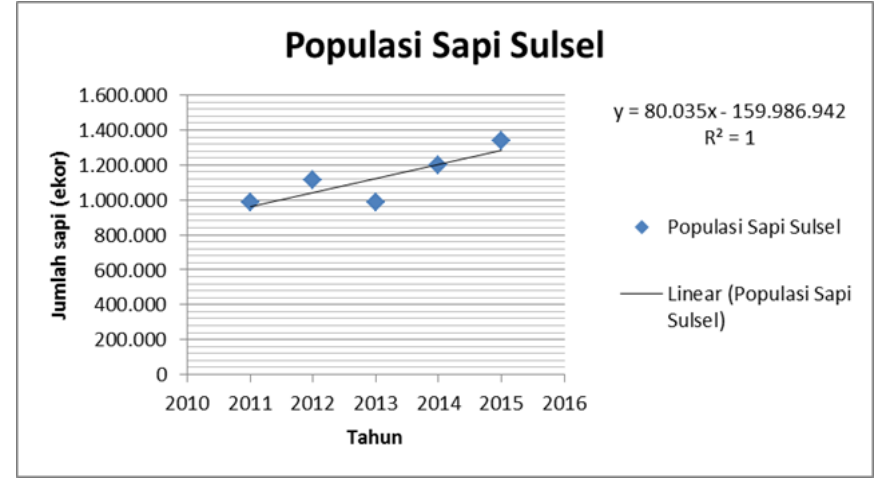

Gambar. 3. Populasi Sapi Sulawesi Selatan

Hasil dari perkiraan jumlah populasi untuk tahun 2016 adalah 3.445 ekor/hari. Kemudian menggunakan metode yang sama perkiraan konsumsi daging sapi untuk daerah Jakarta, Bogor, Depok, Tangerang, Bekasi (Jabodetabek). Pada grafik di bawah dapat dilihat jumlah populasi penduduk Jabodetak tahun 2011-2015.

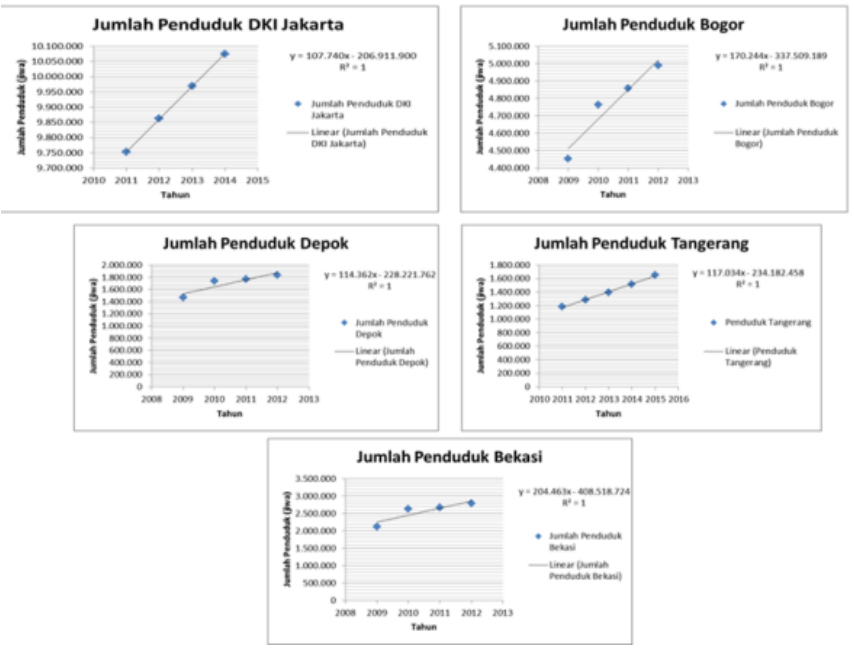

Gambar. 4. Jumlah penduduk Jabodetabek

Dari grafik di atas didapat konsumsi daging sapi untuk penduduk Jabodetabek tahun 2016.
- Jakarta
$=347$ ekor/hari
- Bogor
$=192$ ekor/hari
- Depok
$=79$ ekor/hari
- Tangerang $=60$ ekor/hari
- Bekasi

Total konsumsi daging sapi penduduk Jabodetabek untuk tahun 2016 adalah 802 ekor/hari. Dengan asumsi pengiriman sapi dari Sulawesi Selatan sebesar 15\% dari total kebutuhan, sehingga jumlah pengiriman sapi dari Sulawesi Selatan per hari adalah sebesar 120 ekor/hari. Setelah itu hal yang dilakukan adalah perencanaan waktu. Perencanaan waktu dan muatan yang akan dijadikan sebagai parameter desain kapal ditunjukkan pada tabel 1.

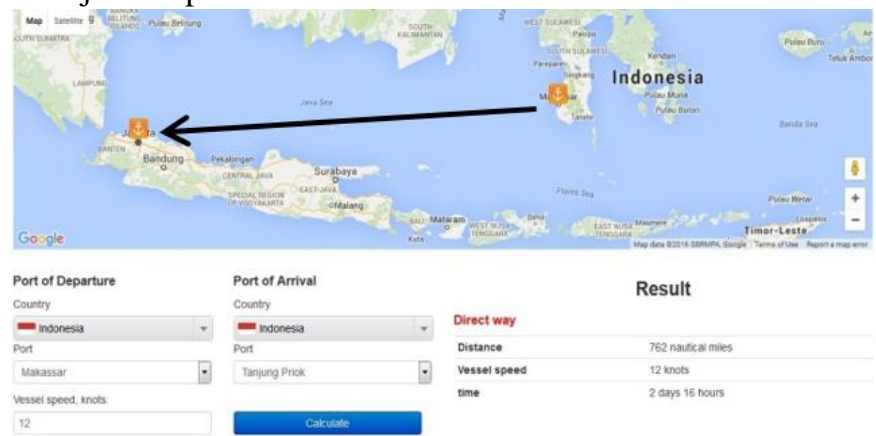

Gambar. 5. Rute pelayaran

Tabel 1.

Estimasi waktu pelayaran

\begin{tabular}{lcc}
\hline \hline \multicolumn{1}{c}{ Item } & Nilai & Satuan \\
\hline Rute Pelayaran Makassar - Jakarta & 762 & mil laut \\
Kecepatan Dinas & 12 & knot \\
Sea Time & 64 & jam \\
Port Time & 75 & jam \\
Roundtrip Time & 203 & jam \\
\hline \hline
\end{tabular}

Sehingga untuk muatan akhir dapat ditentukan dengan jumlah pengiriman sapi dari Sulawesi Selatan per hari dikalikan dengan waktu tempuh (Roundtrip Time).

$$
120 \times 8,46=1.020 \text { ekor }
$$

\section{B. Perencanaan Ukuran}

Setelah mendapatkan jumlah muatan untuk Livestock Carrier, langkah selanjutnya adalah mencari ukuran utama awal. Untuk mencari ukuran utama awal, dibutuhkan layout awal yang menjadi tempat muatan ternak sapi.

Dengan mempertimbangkan kenyamanan dan kesejahteraan ternak sapi, maka didapatkan layout untuk seperti Gambar 6.

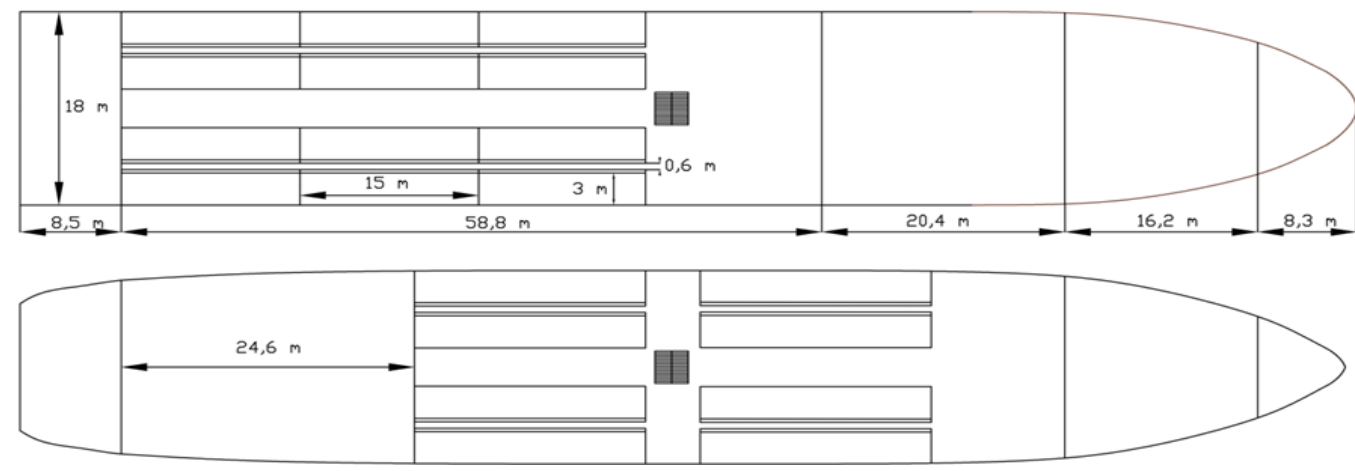

Gambar. 6. Layout awal 
Setelah menentukan ukuran kandang (paddock) ternak, langkah selanjutnya mencari ukuran utama awal sebagai patokan awal yang digunakan untuk merancang Livestock Carrier. Dengan mempertimbangkan layout dan contoh yang sudah ada, maka didapatkan ukuran utama awal sebagai berikut :

$$
\begin{array}{ll}
\text { Lwl } & =108,44 \mathrm{~m} \\
\text { Lpp } & =107,50 \mathrm{~m} \\
\mathrm{~B} & =18,00 \mathrm{~m} \\
\mathrm{H} & =8,00 \mathrm{~m} \\
\mathrm{~T} & =4,20 \mathrm{~m}
\end{array}
$$

C. Pemeriksaan Teknis

Dengan koefisien-koefisien utama:

- $\mathrm{Cb}=0,774$

- $\mathrm{Cm} \quad=0,994$

- $\mathrm{Cp} \quad=0,778$

- Cwp =0,849

- Displasemen $=6.500,019$ ton

1) Hambatan dan Propulsi

Hambatan $($ Holtrop $)=140,47 \mathrm{kN}$

Total propulsi $\quad=2040 \mathrm{HP}$

Mesin Utama $\quad=$ MAN B\&W 61 27/38

2) Hukum Archimedes

LWT

$=3.679,59$ ton

DWT

$=2.495,65$ ton

Total berat kapal

$=6.175,24$ ton

Displacement

$=6.500,019$ ton

3) Freeboard

Kriteria mengharuskan freeboard aktual kapal harus lebih besar dari freeboard minimal dari regulasi.

Freeboard minimal $=1,347$ meter

Freeboard aktual $=3,80$ meter (memenuhi)

4) Stabilitas

Perhitungan stabilitas untuk Livestock Carrier ini menggunakan bantuan software. Pehitungan dengan muatan penuh dan consummable penuh, muatan penuh dan consummable 10\%, muatan kosong dan consummable $100 \%$, dan muatan kosong dan consummable $10 \%$.

Berikut adalah tabel hasil running stabilitas menggunakan software:

Tabel 2.

\begin{tabular}{|c|c|c|c|}
\hline Kriteria & Min & Aktual & Kondisi \\
\hline $\mathrm{e}_{30^{\circ}}$ & 3,1513 & 47,0075 & Diterima \\
\hline $\mathrm{e}_{40^{\circ}}$ & 5,1566 & 76,7011 & Diterima \\
\hline $\mathrm{e}_{30^{\circ}-40^{\circ}}$ & 1,7189 & 29,6936 & Diterima \\
\hline $\mathrm{h}_{30^{\circ}}$ & 0,2 & 3,013 & Diterima \\
\hline$\Theta_{\max }$ & 25 & 38,2 & Diterima \\
\hline $\mathrm{GM}_{0}$ & 0,15 & 5,738 & Diterima \\
\hline
\end{tabular}

Muatan penuh dan consummable $100 \%$

\begin{tabular}{lrrl}
\hline \hline \multicolumn{1}{c}{ Kriteria } & \multicolumn{1}{c}{ Min } & \multicolumn{1}{c}{ Aktual } & Kondisi \\
\hline $\mathrm{e}_{30^{\circ}}$ & & & \\
$\mathrm{e}_{40^{\circ}}$ & 3,1513 & 30,129 & Diterima \\
$\mathrm{e}_{30^{\circ}-40^{\circ}}$ & 5,1566 & 50,9286 & Diterima \\
$\mathrm{h}_{30^{\circ}}$ & 1,7189 & 20,7996 & Diterima \\
$\Theta_{\max }$ & 0,2 & 2,106 & Diterima \\
$\mathrm{GM}_{0}$ & 25 & 34,5 & Diterima \\
\hline \hline
\end{tabular}

Tabel 3.

Muatan penuh dan consummable $10 \%$

Tabel 4.

Muatan kosong dan consummable $100 \%$

\begin{tabular}{lrrr}
\hline \hline \multicolumn{1}{c}{ Kriteria } & \multicolumn{1}{c}{ Min } & \multicolumn{1}{c}{ Aktual } & Kondisi \\
\hline $\mathrm{e}_{30^{\circ}}$ & & & \\
$\mathrm{e}_{40^{\circ}}$ & 3,1513 & 35,9202 & Diterima \\
$\mathrm{e}_{30^{\circ}-40^{\circ}}$ & 5,1566 & 61,2748 & Diterima \\
$\mathrm{h}_{30^{\circ}}$ & 1,7189 & 25,3545 & Diterima \\
$\Theta_{\max }$ & 0,2 & 2,57 & Diterima \\
$\mathrm{GM}_{0}$ & 25 & 36,4 & Diterima \\
\hline \hline
\end{tabular}

Tabel 5 .

Muatan kosong dan consummable $10 \%$

\begin{tabular}{lrrr}
\hline \hline \multicolumn{1}{c}{ Kriteria } & \multicolumn{1}{c}{ Min } & \multicolumn{1}{c}{ Aktual } & Kondisi \\
\hline $\mathrm{e}_{30^{\circ}}$ & & & \\
$\mathrm{e}_{40^{\circ}}$ & 3,1513 & 42,1083 & Diterima \\
$\mathrm{e}_{30^{\circ}-40^{\circ}}$ & 5,1566 & 69,1436 & Diterima \\
$\mathrm{h}_{30^{\circ}}$ & 1,7189 & 27,0352 & Diterima \\
$\Theta_{\max }$ & 0,2 & 2,75 & Diterima \\
$\mathrm{GM}_{0}$ & 25 & 38,2 & Diterima \\
\hline \hline
\end{tabular}

D. Sistem Sanitasi

Sistem sanitasi untuk muatan ternak sapi adalah dengan membuat selokan berukuran $15 \times 15 \mathrm{~cm}$ sepanjang kandang (paddock). Ternak sapi menghasilkan $30 \mathrm{~kg}$ kotoran dan 24 liter urin setiap hari yang membutuhkan tangki sewage berkapasitas 198,622 $\mathrm{m}^{3}$. Karena terbatasnya ruangan di dalam kapal maka digunakan sewage treatment unit sebanyak 8 unit dengan kapasitas $10 \mathrm{~m}^{3}$.

\section{E. Sistematika Bongkar Muat}

Untuk muatan ternak sapi proses bongkar muat dengan menggunakan jembatan rampa. Baik itu saat ternak diangkut dari pelabuhan ke atas kapal, maupun sebaliknya saat ternak turun dari kapal menuju pelabuhan. Selain itu jembatan rampa juga digunakan untuk ternak naik atau turun dari satu geladak ke geladak lainnya. Dalam perencanaan bongkar muat ternak sapi dibuat satu jalan untuk proses loading dan unloading muatan ternak. Sehingga untuk proses loading dan unloading muatan ternak melewati jalan yang sama. Untuk lebih menjelaskan alur proses loading dan unloading, maka dimodelkan dalam gambar 3D. Gambar di bawah ini menunjukkan paddock yang ada di dalam kapal. 


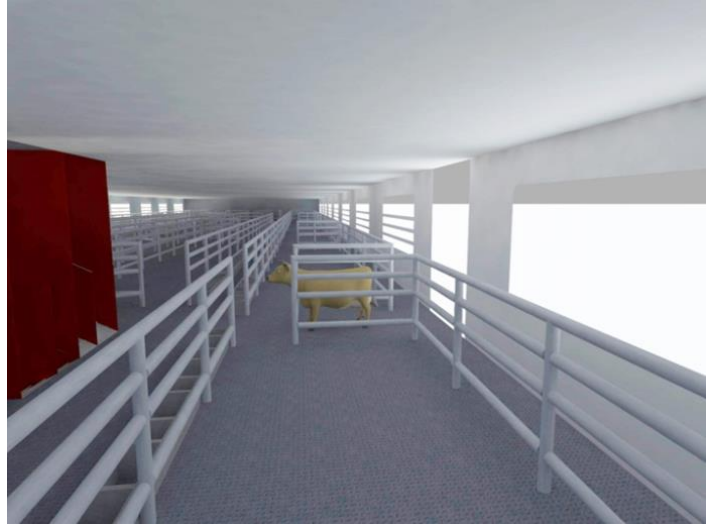

Gambar. 7. Paddock di dalam kapal

Saat berada di atas geladak stockman menggiring ternak sapi dengan alur yang direncanakan seperti ditunjukkan Gambar 8.

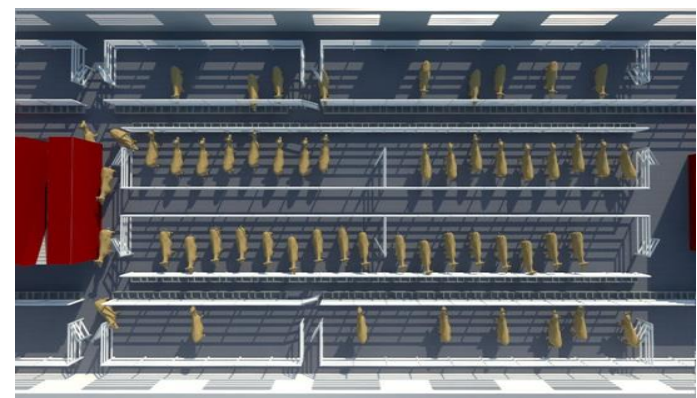

Gambar. 8. Alur masuk sapi tampak atas

\section{F. Rencana Garis dan Rencana Umum}

1) Rencana Garis

Setelah didapatkan ukuran utama akhir dari hasil perhitungan teknis, kemudian dilakukan pembuatan Rencana Garis. Rencana Garis merupakan gambar yang menyatakan bentuk potongan badan kapal dibawah garis air yang memiliki tiga sudut pandang yaitu, body plan (secara melintang), sheer plan (secara memanjang) dan half breadth plan (dilihat dari atas). Dalam pembuatan Rencana Garis ini digunakan perpaduan antara dua software desain. Desain Rencana Garis yang dihasilkan tampak pada Gambar 9.

\section{2) Rencana Umum}

Dari gambar Rencana Garis yang sudah dibuat, maka dapat dibuat pula gambar Rencana Umum dari Livestock Carrier.Rencana Umum didefinisikan sebagai perencanaan ruangan yang dibutuhkan sesuai dengan fungsi dan perlengkapan kapal [6].
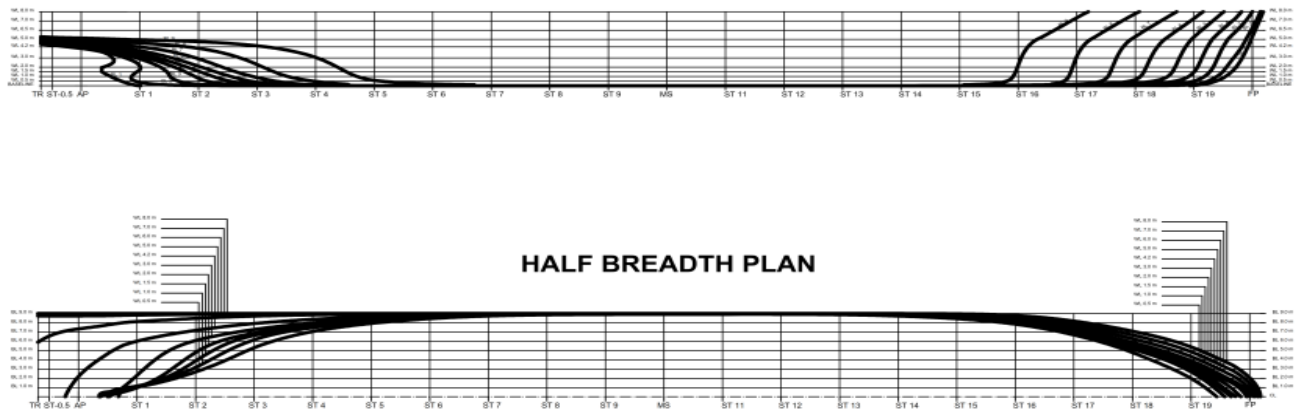

\section{HALF BREADTH PLAN}

Gambar. 9. Rencana garis

Hal-hal yang harus diperhatikan dalam pembuatan Rencana Umum Livestock Carrier ini adalah penataan geladak pada kapal yang baik agar memberikan ruang yang pas untuk penempatan kandang (paddock) ternak sapi. Kemudian hal yang harus dipertimbangkan juga adalah desain sistem sanitasi agar muat di dalam kapal tanpa mengurangi fungsinya. Desain Rencana Umum yang dihasilkan tampak pada Gambar 10. 


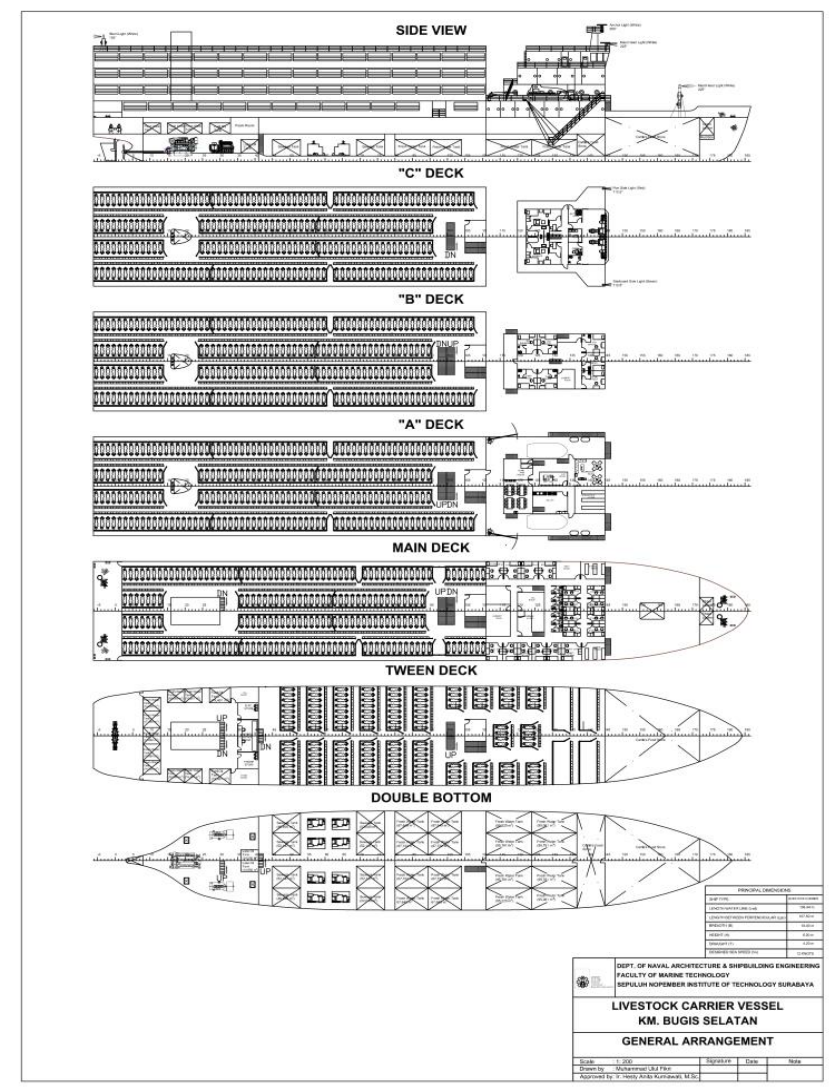

Gambar. 10. Rencana umum

\section{KESIMPULAN}

Setelah proses desain dari Jurnal ini terselesaikan maka didapat kesimpulan sebagai berikut. Dari analisis teknis desain Livestock Carrier, dapat ditarik kesimpulan sebagai berikut:

1) Dari hasil analisis yang telah dibuat, didapat payload untuk kapal Livestock Carrier ini sebesar 1020 ekor. Rute pelayaran dari Pelabuhan Soekarno - Hatta di Makassar menuju Pelabuhan Tanjung Priok di Jakarta dengan jarak tempuh pelayaran adalah 762 mil laut.

2) Dari hasil perhitungan dan analisis, didapat ukuran utama kapal akhir Livestock Carrier untuk rute Makassar Jakarta yaitu:
- Lwl
$=108,44 \mathrm{~m}$
- Displasemen
$=107,50 \mathrm{~m}$
- B
$=8,00 \mathrm{~m}$
- $\mathrm{H}$
$=8,00 \mathrm{~m}$
- $\mathrm{T}$
$=4,20 \mathrm{~m}$

Livestock Carrier ini telah memenuhi persyaratan teknis dari pembangunan sebuah kapal yaitu batasan trim, freeboard, displasemen, dan stabilitas.

3) Sewage treatment plant metode biologis digunakan untuk sistem sanitasi di dalam kapal. Sebanyak 8 unit sewage treatment unit dengan kapasitas $10 \mathrm{~m}^{3}$ per hari digunakan di dalam kapal untuk menjadi sistem sanitasi dalam kapal bekerja dengan baik.

\section{UCAPAN TERIMA KASIH}

Penulis mengucapkan rasa syukur dan terima kasih sebanyak-banyaknya atas doa dan dukungan dari orang tua. Penulis juga mengucapkan terima kasih sebanyak-banyak kepada Ir. Hesty Anita Kurniawati yang telah membimbing dalam menyelesaikan Jurnal ini. Selain itu tak lupa penulis sampaikan ucapan terima kasih kepada rekan-rekan Jurusan Teknik Perkapalan yang telah menjadi kawan berjuang dalam menyelesaikan studi di perguruan tinggi.

\section{DAFTAR PUSTAKA}

[1] D. Rayanti, "Sapi Asal NTT Belum Cukup Penuhi Kebutuhan Daging di DKI Jakarta," 26 Desember 2015. [Online]. Available: http://finance.detik.com/read/2015/12/26/164533/3104637/4/sapi-asal-nttbelum-cukup-penuhi-kebutuhan-daging-di-dki-jakarta.

[2] C. Subiyantoro and A. Z. Fanan, "Desain Konseptual Kapal Pengangkut Sapi," Jurusan Transportasi Laut FTK - ITS, Surabaya, 2015.

[3] F. Fabiansa, "Studi Sistem Sanitasi dan Ventilasi pada Ruang Muat Kapal Generasi Cargo yang Dikonversi Menjadi Livestock Carrier," Tugas Akhir Jurusan Teknik Sistem Perkapalan FTK - ITS, Surabaya, 2010.

[4] V. Annisa, "Optimasi Desain Tata Letak Ruang Muat Livestock Carrier untuk Meningkatkan Distribusi Ternak antar Pulau di Indonesia," Tugas Akhir Jurusan Teknik Perkapalan FTK - ITS, Surabaya, 2016.

[5] Badan Pusat Statistik Provinsi Sulawesi Selatan, "Jumlah Penduduk Sulawesi Selatan Menurut Kota/ Kabupaten Tahun 2011-2014," Badan Pusat Statistik Sulawesi Selatan, Desember 2015. [Online]. Available: http://sulsel.bps.go.id/linkTabelStatis/view/id/31. [Accessed 25 Februari 2016].

[6] R. Taggart, Ship Design and Construction, New York: The Society of Naval Architects and Marine Engineers, 1980. 